\title{
Insulin Pump Therapy: Its Effect on Metabolic Control in Different Age Groups in Children with Type 1 Diabetes
}

\section{Insülin Pompa Tedavisi: Farklı Yaș Gruplarındaki Tip Diyabetli Çocuklarda Metabolik Kontrole Üzerine Olan Etkisi}

\author{
Samim Özen, Damla Gökşen, Günay Demir, Şükran Darcan \\ Ege University Faculty of Medicine, Department of Pediatric Endocrinology, Izmir, Turkey
}

\begin{abstract}
Aim: To evaluate the effect of continuous subcutaneous insulin infusion (CSII) pump treatment on metabolic control in different age groups in children with type 1 diabetes mellitus.

Materials and Methods: Fifty-nine children and adolescents with type 1 diabetes, aged between 2.4-18.3 years, with diabetes duration of 7.4 \pm 4.0 years, in whom CSII was performed were divided into 4 groups according to their ages at baseline of CSII. Metabolic control was evaluated according to body measurements before and after CSII treatment, daily basal insulin requirements (u/kg-day), hemoglobin A1c and lipid levels. Children were evaluated at the end of the first and second years of treatment.

Results: At the end of the first year a significant and sustained decreases were observed in the mean hemoglobin A1c levels in pre-school and preadolescent groups (from $8.91 \pm 0.52 \%$ to $6.83 \pm 0.68 \%$; from $7.15 \pm 0.56 \%$ to $6.73 \pm 0.45 \%, p<0.05$, respectively), whereas insignificant decreases were observed in groups 3 and 4 . At the end of the $2^{\text {nd }}$ year in overall evaluation, mean hemoglobin A1c levels decreased persistently but insignificantly. Better diabetic control with lower basal insulin requirement was provided with insulin pump treatment. There was no significant changes in serum total cholesterol, low density lipoprotein, and high density lipoprotein levels. Significant increase in body mass index (BMI), standard deviation score (SDS) with CSIl treatment was only detected in group $3\left(-0.2\right.$ vs $\left.0.46 \mathrm{~kg} / \mathrm{m}^{2}, \mathrm{p}=0.00\right)$. Conclusion: Although CSII has a positive effect on metabolic control in type 1 diabetes mellitus treatment at all age groups of childhood, it is prominent and sustained especially at preschool and preadolescent periods. However, it is difficult to sustain the same positive effect in the older age groups. CSII treatment provides a better diabetic control without increased basal insulin requirements. The Journal of Pediatric Research 2014; 1(3):147-51
\end{abstract}

Key Words: Childhood, insulin infusion systems, type 1 diabetes mellitus
ÖZET

Amaç: Sürekli cilt altı insülin infüzyon (SCil) tedavisinin metabolik kontrol üzerine olan etkisini çocukluk çağındaki farklı yaş gruplarına göre değerlendirmek.

Gereç ve Yöntem: Yaşları 2,4 ile 18,3 yıl arasında değişen, diyabet süreleri $7,4 \pm 4,0$ yl, insülin infüzyon tedavisi uygulanan 59 tip 1 diyabetes mellitus (T1DM) tanılı çocuk ve ergen SCil tedavisi başlangıcındaki yaşlarına göre 4 gruba ayrıldı. Hastaların SCil tedavisi başlanması öncesi ve sonrasında vücut ölçümleri, günlük bazal insülin ihtiyaçları (ü/kg/gün) metabolik kontrol değerlendirmek amacıyla hemoglobin A1c (HbA1c) ve lipid düzeyleri çalışıldı. SCil tedavisinin 1. ve 2. yllında olgular değerlendirildi.

Bulgular: Pompa tedavisinin 12. ayından sonra okul öncesi ve ergen öncesi gruplarda ortalama $\mathrm{HbA1c}$ de anlamlı ve kalıcı bir azalma (sırası ile $\% 8,91 \pm 0,52$ 'den $6,83 \pm 0,68^{\prime}$ e ve $\% 7,15 \pm 0,56$ 'dan $\% 6,73 \pm 0,45^{\prime}$ e, $p<0,05$ ) saptanırken grup 3 ve 4'de anlamlı olmayan azalma gözlendi. Insülin pompa tedavisi ile daha düşük bazal insülin intiyacı ile daha iyi bir diyabet kontrolü sağlandı. SCil tedavisi ile hastaların serum total kolesterol, LDL ve HDL kolesterol düzeylerinde anlamlı bir değişiklik olmadı. Beden kitle indeksi (BKI) standart deviasyon skoru'nda (SDS) sadece grup 3'de anlamlı artış bulundu $\left(-0,2\right.$ vs. $\left.0,46 \mathrm{~kg} / \mathrm{m}^{2} \mathrm{ye}, \mathrm{p}=0,00\right)$.

Sonuç: T1DM tedavisinde SCil'nin çocukluk çağında tüm yaş gruplarında metabolik kontrol üzerine olumlu etkisi olmakla birlikte özellikle okul öncesi ve pre-adolesan grupta bu etki daha belirgin ve kalıııdır. Büyük yaş gruplarında aynı olumlu etkiyi sürdürmek zordur. T1DM'li çocuk ve adolesanlarda SCil tedavisi ile günlük bazal insülin ihtiyacı artmadan daha iyi bir diyabet kontrolü sağlanabilmektedir. The Journal of Pediatric Research 2014;1(3):147-51 Anahtar Kelimeler: Çocukluk çağı, insulin infüzyon sistemi, tip 1 diyabetes mellitus 


\section{Introduction}

Near normal blood glucose and hemoglobin A1c (HbA1c) levels should be provided in children with type 1 diabetes mellitus (T1DM) to prevent micro and macrovascular complications or to delay their appearances (1). For this purpose, continuous subcutaneous insulin infusion (CSII) treatment is being employed intensely in recent years with the help of technological improvements (2). It is reported in many studies that better metabolic control $(7.4 \pm 4.0$ years), fewer severe hypoglycemia episodes and higher life qualities of patients are provided by CSII treatment $(2,4-8)$. In a metaanalysis including 22 studies in children and adults, $\mathrm{HbA} 1 \mathrm{c}$ has decreased $0.21-0.72 \%$ with CSII treatment 3 . Insulin requirements, diabetes care requirements and metabolic control success may show differences according to different age groups in children with T1DM different from adults. It is already known that metabolic control of T1DM is more difficult especially in preschool and adolescent periods than the other age groups in childhood, so existent insulin treatment methods patients are using is tried to be simplified or changed (9-11).

This present study aims to define the effect of CSII treatment on metabolic control and auxological characteristics of diabetic children and adolescents in different age groups.

\section{Material and Methods}

Fifty-nine children and adolescents with a diagnosis of T1DM (32 female/27 male) at least for 1 years (mean diabetes duration was $7.4 \pm 4.0$ years), who were on CSII treatment and were still followed up at the Ege University, Department of Pediatric Endocrinology were included into the study. The mean age of the patients were $14.4 \pm 5.3$ years (2.4-18.3 years) children and adolescents were grouped into 4 according their baseline ages and they are defined as group 1 (<4.9 years), group 2 (5-9.9 yrs), group 3 (10-14.9 years) and group 4 ( $>15$ years). Before CSII treatment, training and practicing session were provided for all the patients by the same experienced pediatric endocrinologist and diabetes nurse. Total daily insulin doses were decreased by $10 \%$ and $40 \%$ of this calculated insulin amount was adjusted as basal insulin. Absolute basal insulin requirements for patients for various times of day have been adjusted by outpatient control or phone calls. All patients used the same insulin pump (MiniMed, Medtronic, USA) and aspartate insulin. They were required to practice self-blood glucose monitoring at least 8 times in a day and their records of glucose monitoring devices were controlled. Before and after initiation of CSII treatment, auxologic characteristics, daily basal insulin requirements $(\mathrm{U} / \mathrm{kg} / \mathrm{day}), \mathrm{HbA} 1 \mathrm{c}$ levels of patients every 3 months, were recorded prospectively; training of the patients were repeated in the requiring patients. At the beginning, daily basal insulin uses were obtained from the medical records, and during the follow up they were obtained from downloaded pump data to the computer. Height was measured to the nearest centimeter using a rigid stadiometer. Weight was measured unclothed to the nearest $0.1 \mathrm{~kg}$ using a calibrated balance scale. Body mass index (BMI) is calculated by weight $(\mathrm{kg}) /$ height $\left(\mathrm{m}^{2}\right)$ formula. Standard deviation scores (SDS) according to age and gender are calculated for weight, height and BMI of Turkish children (12). HbA1c examinations are performed in every 3 months by a capillary method with Nycocard II Reader (Axis-Shield Diagnostics Ltd, Dundee, UK) device, and annual mean $\mathrm{HbA} 1 \mathrm{c}$ levels are calculated as an indicator of metabolic control. Fasting TC, LDL, HDL, levels of patients are measured in the morning with a Beckman Coulter UniCel ${ }^{\circledR}$ automatic analyzer.

The authors confirmed in writing that they have complied with the World Medical Association Declaration of Helsinki regarding ethical conduct of research involving human subjects and/or animals. The study was approved by the local ethical board and informed consent was obtained from the families of all patients.

\section{Statistical Analysis}

Data analyses were performed with SPSS for Windows (version 15 SPSS Inc., Chicago, IL, USA). Patient characteristics were determined using descriptive statistics. Independent $t$ test and one-way ANOVA test with Bonferroni's correction for multiple comparisons were used to compare the means of groups when appropriate. Statistically significance level was accepted as $p<0.05$.

\section{Results}

Mean age of patients was $14.4 \pm 5.3$ years, mean duration of diabetes was $7.4 \pm 4.0$ years. $54.2 \%$ was female and $45.8 \%$ was male, and all of participants were receiving multiple dose short acting insulin analogues and long acting basal insulin at baseline of the study. Demographic and auxologic characteristics of the patients in the four age groups are given in Table I. While baseline mean $\mathrm{HbA} 1 \mathrm{c}$ in group 1 (mean age is $<5$ years) were statistically significantly higher than the other groups $(p<0.05)$, there was no statistically significant difference between the rest. Baseline mean values of $\mathrm{HbA} 1 \mathrm{c}$ for all patients was $7.67 \pm 1.25 \%$; whereas after 1 st and $2^{\text {nd }}$ years $7.15 \pm 1.12 \%$ and $7.32 \pm 1.24 \%$, respectively. When all ages were evaluated generally with CSII treatment, there was a sustained but insignificant decreases in mean $\mathrm{HbA} 1 \mathrm{c}$ values $(p>0.05)$. When it was re-evaluated after patients were divided into age groups, pump treatment at the end of first year caused significant decrease in mean $\mathrm{HbA} 1 \mathrm{c}$ values in group 1 and 2 (from $8.91 \%$ to $7.41 \%$ and from $7.15 \%$ to $6.58 \% ; p<0.05)$; and at the end of second year the decrease was sustained (mean $\mathrm{HbA} 1 \mathrm{c}$ at the end of $2^{\text {nd }}$ year $6.83 \%$ and $6.73 \%$; respectively). Although mean $\mathrm{HbA} 1 \mathrm{c}$ values of group 3 and 4 were decreased at the end of first year, results were not statistically significant ( $p>0.05$ ) (Table II).

Means of $T C, L D L$, and $H D L$ values at the baseline of pump treatment were $174.9 \pm 34.7 \mathrm{mmol} / \mathrm{L} ; 87.0 \pm 23.4$ $\mathrm{mmol} / \mathrm{L}$, and $62.7 \pm 15.5 \mathrm{mmol} / \mathrm{L}$, respectively. Means of the values at the end of second year were $169.9 \pm 35.5 \mathrm{mmol} / \mathrm{L}$, 
$85.8 \pm 21.4 \mathrm{mmol} / \mathrm{L}$, and $62.1 \pm 16.3 \mathrm{mmol} / \mathrm{L}$, respectively and there was no difference when they were compared with the baseline values ( $p>0.05)$. When evaluated according to age groups, there was no statistically significant difference between baseline and 1 st, $2^{\text {nd }}$ year values for all age groups (in all age groups $\mathrm{p}>0.05$ ).

Baseline basal insulin requirements, which was calculated as per $\mathrm{kg}$ of body weight, were similar in four different age groups ( $p>0.05)$. However, it is demonstrated that basal insulin requirements were statistically significantly decreased in all age groups with CSII treatment $(p<0.05)$. However, there was no difference in daily basal insulin requirements of patients between the first and second years. Significant increase in BMI with CSII treatment was only detected in Group 3 (from -0.2 to 0.46). During the follow up, although $\mathrm{BMI}$ was increased in respect to baseline in other age groups, this change was not statistically significant $(p>0.05)$. It was demonstrated that basal insulin requirements, $\mathrm{HbA} 1 \mathrm{c}$, and BMI SDS values did not differ in respect to gender at baseline, at the end of first and second years ( $p>0.05$ ).

\section{Discussion}

Since children are growing organisms their nutritional habits, life style and metabolic status show continuous changes with age. It is quite difficult to take diabetes under control in children with T1DM because of contiguous variations in children and especially in adolescents because of the compliance problems $(9,10)$. Therefore, CSII, which is a quite similar treatment method with physiological secretion of insulin and increases life quality of patients by providing a flexible life style, becomes frequently employed in recent years in children (2-8). Many studies have reported that CSII treatment is a safe and effective method to elicit diabetes control $(2-8,11)$.

This present study has been based on the hypothesis that effect of CSII treatment could differ in metabolic control in childhood in respect to the age. Therefore, after the patients were evaluated for metabolic control before CSII treatment, their follow up data were collected prospectively at the first and second years. CSII treatment was reported

Table I. Patient demographic, auxologic characteristics, HbA1c levels and daily basal insulin requirements at the baseline

\begin{tabular}{|l|l|l|l|l|}
\hline & $\begin{array}{l}\text { Group } \mathbf{1} \\
(<4.9 \text { years })\end{array}$ & $\begin{array}{l}\text { Group 2 } \\
\mathbf{( 5} \text { to }<\mathbf{9 . 9} \text { years })\end{array}$ & $\begin{array}{l}\text { Group 3 } \\
(\mathbf{1 0} \text { to }<14.9 \text { years })\end{array}$ & $\begin{array}{l}\text { Group } \mathbf{4} \\
(>\mathbf{1 5} \text { years })\end{array}$ \\
\hline $\mathrm{n}$ & 6 & 12 & 12 & 29 \\
\hline Age (years) & $4.2 \pm 1.1$ & $8.7 \pm 1.5$ & $13.4 \pm 1.7$ & $18.3 \pm 2.1$ \\
\hline Girls, $\mathrm{n}(\%)$ & $2(33.3)$ & $5(41.6)$ & $8(66.6)$ & $16(55.1)$ \\
\hline Mean duration of diabetes (years) & $2.8 \pm 0.9$ & $5.2 \pm 0.9$ & $6.9 \pm 3.3$ & $9.5 \pm 4.1$ \\
& $(1.1-4.0)$ & $(4.0-6.8)$ & $(2.9-11.0)$ & $(3.2-16.1)$ \\
\hline Height-SDS & $-0.31 \pm 1.11$ & $-0.22 \pm 1.01$ & $-0.30 \pm 1.61$ & $0.64 \pm 1.12$ \\
\hline Weight-SDS & $-0.25 \pm 0.71$ & $-0.24 \pm 0.99$ & $-0.25 \pm 1.04$ & $0.32 \pm 1.06$ \\
\hline BMI-SDS & $0.81 \pm 1.71$ & $0.42 \pm 0.60$ & $-0.21 \pm 0.67$ & $0.04 \pm 0.76$ \\
\hline HbA1c (\%) & $8.91 \pm 0.52$ & $7.15 \pm 0.56$ & $7.41 \pm 1.38$ & $7.89 \pm 1.64$ \\
\hline Basal insulin (IU/kg/d) & $0.50 \pm 0.24$ & $0.48 \pm 0.21$ & $0.52 \pm 0.22$ & $0.55 \pm 0.25$ \\
\hline
\end{tabular}

Data are given as mean \pm SD, SDS: Standard deviation score, BMI: Body mass index

Table II. Mean HbA1c values before, during and after the pump treatment

\begin{tabular}{|l|l|l|l|}
\hline & $\begin{array}{l}\text { Mean } \\
\text { HbA1c (\%) } \\
\text { Baseline }\end{array}$ & $\begin{array}{l}\text { Mean } \\
\text { HbA1c (\%) } \\
\text { At the end of year 1 }\end{array}$ & $\begin{array}{l}\text { Mean } \\
\text { HbA1c (\%) } \\
\text { At the end of year 2 }\end{array}$ \\
\hline $\begin{array}{l}\text { Group } 1^{* *} \\
(\mathrm{n}=6)\end{array}$ & $\begin{array}{l}8.91 \pm 0.52 \\
\begin{array}{l}\text { Group 2** } \\
\text { (n=12) }\end{array}\end{array}$ & $7.41 \pm 0.48^{*}$ & $6.83 \pm 0.68$ \\
\hline $\begin{array}{l}\text { Group 3 } \\
\text { (n=12) }\end{array}$ & $7.15 \pm 0.56$ & $6.58 \pm 0.47^{*}$ & $6.73 \pm 0.45$ \\
\hline $\begin{array}{l}\text { Group 4 } \\
\text { (n=29) }\end{array}$ & $7.41 \pm 1.38$ & $7.01 \pm 0.80$ & $7.23 \pm 0.94$ \\
\hline
\end{tabular}

Data are given as mean $\pm S D,{ }^{*} p<0.05$ Groups 1 and 2 (First year), ${ }^{* *} p<0.05$ Groups 1 and 2 (At all times during the study) 
to decrease $\mathrm{HbA} 1 \mathrm{c}$ in the recently published consensus report, which was conducted on more than 760 children and included results of observation studies (2). Among other studies, which evaluated effects of CSII on metabolic control, Shalitin et al. (13) reported from their retrospectively conducted study on 421 T1DM patients aging between 2.6 and 39.8 years (median: 19.4 years) that $\mathrm{HbA} 1 \mathrm{c}$ levels were prominently decreased with CSII treatment in especially patients younger than 12 years of age. It was reported in another study, which was conducted in 17 countries on 1041 children and adolescents $(11.8 \pm 4.2$ years) with T1DM receiving CSII treatment, that glycemic control at the preschool children and pre-adolescent patients were better than that of in the adolescents (11). In our study, while there was statistically significant improvement in participants younger than 10 years (group 1 and 2), who received CSII treatment for the metabolic control at the first year, the improvement was also demonstrated to be sustained at the end of $2^{\text {nd }}$ year. However, there was a statistically insignificant improvement in CSII treatment at the end of first year when compared with the baseline in group 3 and 4 (older than 10 years). Although $\mathrm{HbA} 1 \mathrm{c}$ values in these age groups were not statistically significant, there was the rising tendency in the $2^{\text {nd }}$ year when compared with the values at the end of first year (Table II). These results might imply that CSII treatment in early ages was successful in metabolic control initiation and its maintenance. Nabhan et al. (14) performed a study on 21 children with T1DM, who were below 5 years of age, and they reported that although $\mathrm{HbA} 1 \mathrm{c}$ values were significantly decreased at the $3^{\text {rd }}$ month of CSII treatment from $8.9 \pm 0.6 \%$ to $8.5 \pm 0.7 \%(p=0.002)$; there was no significant difference in respect to the baseline at the $12^{\text {th }}$ month (HbA1c: $8.8 \pm 0.6 \%)$. Further large scale and long term studies are required to make the final conclusion in this topic, because number of cases was few and follow up periods were not adequately long. The cases in our study are still being followed up.

Previous studies revealed that basal insulin requirements in CSII treatments were less than those in MDI treatment $(2,15)$. In our study, we have demonstrated that basal insulin requirements were prominently decreased in all age groups at the end of the first year. Basal insulin requirements were not increased at the end of the second year when compared with requirements at the baseline and end of the second year. Our study has indicated that better control of diabetes in children and adolescents with T1DM can be provided without increased daily basal insulin requirements by CSII treatment.

It is reported in the published long and short term observational studies that BMI was not increased, but even decreased, by the CSII treatment $(2,16,17)$. When BMI values after CSII treatment were evaluated in our study, BMI SDS increase at the end of second year was statistically significant compared with baseline only in group 3 (10-15 years old) (from $-0.21 \pm 0.67$ to $0.46 \pm 0.60 ; p=0.00$ ). This difference may have been caused by the low baseline BMI in group 3. Although increase in BMI in other age groups was noteworthy, they were insignificant. BMI increases during CSII treatment may be resulted from flexible nutritional style with this treatment. However, factors, which may lead to BMI increase in group 3 have not been investigated in this study. Also, this increase in BMI in this group may be associated with rapid growth spurt other than CSII treatment. In our study, there was no difference in serum lipid levels after the CSII treatment. Among previous studies conducted on this issue, Abaci et al. (8) have not reported any changes in lipid values of T1DM patients, who received CSII treatment and were followed up for a mean duration of 2 years. In another study conducted on T1DM patients it has been reported that CSII treatment had no effect on serum lipid levels (18).

Although the blood glucose was checked 8 times/day we did not analyzed this data. Since the frequency of hypoglyceamia can affect metabolic control this is a limitation for our study.

In conclusion, insulin pump treatment can be employed as an effective alternative method to multiple dose injection treatment in T1DM children of all age groups. However, influences of CSII treatment on metabolic control are more effective and sustained in pre-adolescent and pre-school aged children when compared especially with patients in the older age groups. Although there is an improvement in metabolic control, but not significant, especially in the first year of treatment in children of older age groups, it is hard to maintain this positive effect in later phases. A better diabetes control can be provided in daily basal insulin requirement without any increases in children and adolescents with T1DM by CSII treatment. Further large scale studies with longer durations are required in these issues.

Conflicts of Interest: The authors reported no conflict of interest related to this article.

\section{References}

1. The effect of intensive diabetes treatment on the development and progression of long-term complications in insulin-dependent diabetes mellitus. The Diabetes Control and Complications Trial and Research Group. N Engl J Med 1993; 329: 977-86.

2. Phillip M, Battelino T, Rodriguez H, Danne T, Kaufman F; European Society for Paediatric Endocrinology; Lawson Wilkins Pediatric Endocrine Society; International Society for Pediatric and Adolescent Diabetes; American Diabetes Association; European Association for the Study of Diabetes. Use of insulin pump therapy in the pediatric agegroup: consensus statement from the European Society for Paediatric Endocrinology, the Lawson Wilkins Pediatric Endocrine Society, and the International Society for Pediatric and Adolescent Diabetes, endorsed by the American Diabetes Association and the European Association for the Study of Diabetes. Diabetes Care 2007; 30: 1653-62.

3. Pickup JC, Sutton AJ. Severe hypoglycemia and glycemic control in Type 1 diabetes: meta-analysis of multiple daily insulin injections compared with continuous subcutaneous insulin infusion. Diabet Med 2008; 25: 765-74.

4. Pankowska E, Btazik M, Dziechciarz P, Szypowska A, Szajewska $H$. Continuous subcutaneous insulin infusion vs. multiple daily injections in children with type 1 diabetes: a systematic review and meta-analysis of randomized control trials. Pediatr Diabetes 2009; 10: 52-8. 
5. Nuboer R, Borsboom GJ, Zoethout JA, Koot HM, Bruining $\mathrm{J}$. Effects of insulin pump vs. injection treatment on quality of life and impact of disease in children with type 1 diabetes mellitus in a randomized, prospective comparison. Pediatr Diabetes 2008; 9: 291-6.

6. Jakisch BI, Wagner VM, Heidtmann B, Lepler R, Holterhus PM, Kapellen TM, Vogel C, Rosenbauer J, Holl RW; German/ Austrian DPV Initiative and Working Group for Paediatric Pump Therapy. Comparison of continuous subcutaneous insulin infusion (CSII) and multiple daily injections (MDI) in paediatric Type 1 diabetes: a multicentre matched-pair cohort analysis over 3 years. Diabet Med 2008; 25: 80-5.

7. Kapellen TM, Heidtmann B, Bachmann J, Ziegler R, Grabert $\mathrm{M}$, Holl RW. Indications for insulin pump therapy in different age groups: an analysis of 1,567 children and adolescents. Diabet Med 2007; 24: 836-42.

8. Abaci A, Atas A, Unuvar T, Demir K, Bober E, Büyükgebiz A. A comparison of multiple daily insulin therapy with continuous subcutaneous insulin infusion therapy in adolescents with type 1 diabetes mellitus: a single-center experience from Turkey. J Pediatr Endocrinol Metab 2009; 22: 539-45.

9. Silverstein $\mathrm{J}$, Klingensmith $\mathrm{G}$, Copeland $\mathrm{K}$, Plotnick L, Kaufman F, Laffel L, Deeb L, Grey M, Anderson B, Holzmeister LA, Clark N: American Diabetes Association. Care of children and adolescents with type 1 diabetes: a statement of the American Diabetes Association. Diabetes Care 2005; 28: 186-212.

10. Acerini CL, Cheetham TD, Edge JA, Dunger DB. Both insulin sensitivity and insulin clearance in children and young adults with type I (insulin-dependent) diabetes vary with growth hormone concentrations and with age. Diabetologia 2000; 43: $61-8$

11. Danne $T$, Battelino $T$, Jarosz-Chobot $P$, Kordonouri $O$, Pánkowska E, Ludvigsson J, Schober E, Kaprio E, Saukkonen T, Nicolino $M$, Tubiana-Rufi $N$, Klinkert $C$, Haberland $H$, Vazeou A, Madacsy L, Zangen D, Cherubini V, Rabbone I, Toni S, de Beaufort C, Bakker-van Waarde $W^{\prime}$, van den Berg N, Volkov I, Barrio R, Hanas R, Zumsteg U, Kuhlmann
B, Aebi C, Schumacher U, Gschwend S, Hindmarsh $P$, Torres M, Shehadeh N, Phillip M; PedPump Study Group. Establishing glycemic control with continuous subcutaneous insulin infusion in children and adolescents with type 1 diabetes: experience of the PedPump Study in 17 countries. Diabetologia 2008; 51: 1594-601.

12. Neyzi $\mathrm{O}$, Gunoz $H$, Furman $A$, et al. Türk Çocuklarında vücut ağırlığı, boy uzunluğu, baş çevresi ve vücut kitle indeksi referans değerleri. Çocuk Sağlığı ve Hastalıkları Dergisi 2008; 51: 1-14.

13. Shalitin S, Gil M, Nimri R, de Vries L, Gavan MY, Phillip M. Predictors of glycaemic control in patients with Type 1 diabetes commencing continuous subcutaneous insulin infusion therapy. Diabet Med 2010; 27:339-47.

14. Nabhan ZM, Kreher NC, Greene DM, Eugster EA, Kronenberger W, DiMeglio LA. A randomized prospective study of insulin pump vs. insulin injection therapy in very young children with type 1 diabetes: 12-month glycemic, BMI, and neurocognitive outcomes. Pediatr Diabetes 2009; 10: 202-8.

15. Minkina-Pedras $M$, Jarosz-Chobot P, Polanska J, Kalina MA, Marcinkowski A, Malecka-Tendera E. Prospective assessment of continuous subcutaneous insulin infusion therapy in young children with type 1 diabetes. Diabetes Res Clin Pract 2009; 85:153-8.

16. Weintrob N, Benzaquen $H$, Galatzer A, Shalitin $S$, Lazar L, Fayman G, Lilos P, Dickerman Z, Phillip M. Comparison of continuous subcutaneous insulin infusion and multiple daily injection regimens in children with type 1 diabetes: a randomized open crossover trial. Pediatrics 2003; 112: 559-64.

17. Wood JR, Moreland EC, Volkening LK, Svoren BM, Butler DA, Laffel LM. Durability of insulin pump use in pediatric patients with type 1 diabetes. Diabetes Care 2006; 29: 2355-60.

18. Bruttomesso D, Crazzolara D, Maran A, Costa S, Dal Pos M, Girelli A, Lepore G, Aragona M, lori E, Valentini U, Del Prato S, Tiengo A, Buhr A, Trevisan R, Baritussio A. In Type 1 diabetic patients with good glycaemic control, blood glucose variability is lower during continuous subcutaneous insulin infusion than during multiple daily injections with insulin glargine. Diabet Med 2008; 25: 326-32. 